\title{
Komunikasi Downward Dalam Peningkatan Produktivitas PT. Sasa Inti
}

\author{
${ }^{1}$ Herfira Apriyanti, ${ }^{2}$ Riyanto \\ ${ }^{1,2}$ Sekolah Tinggi Ilmu Komunikasi InterStudi.Jl. Wijaya II/62 Kebayoran Baru, Jakarta Selatan \\ E-mail : riyantocawas67@gmail.com
}

\begin{abstract}
Abstrak. Era globalisasi terjadi dengan kecepatan tinggi menyentuh aspek kehidupan manusia, menerobos dinding geografis, kebangsaan, kebudayaan dan peradaban dunia sehingga muatan global tidak dapat dicegah dan berkembang transparan terhadap perkembangan informasi. Komunikasi organisasi adalah pengiriman dan penerimaan pesan di dalam kelompok formal maupun informal, untuk membentuk saling pengertian dan mempunyai andil, berdampak membangun budaya organisasi. Produktivitas perbandingan antara hasil luaran dengan masukan. Dan pemanfaatkan menghasilkan barang atau jasa. Semakin tinggi perbandingannya, semakin tinggi produkyang dihasilkan. Aspek output atau input yang digunakan indeks produktivitas buruh, produktivitas biaya langsung, produktivitas biaya total, produktivitas produksi.PT Sasa Inti sebagai obyek penelitian karena masih bertahan di tengah perkembangan dan persaingan bisnis industri yang ketat. Keberhasilan komunikasi mendorong karyawan menghasilkan Sasa yang semakin meningkat karena merasa bahwa pimpinan dapat menjalin komunikasi yang baik dengan mereka.Komunikasi binis, tidak terlepas produksi, pembelian, penjualan, maupun pertukaran barang dan jasa yang mempunyai tujuan laba untuk kelangsungan kegiatan bisnis itu. Bisnis adalah kegiatan komersial dan industrial yang menghasilkan barang dan jasa untuk meningkatkan dan mempertahankan kehidupan, berorientasi dan tanggung jawab sosial penyediaan barang dan jasa Komunikasi downward merupakan bagian komunikasi organisasi yang merujuk pada pertukaran informasi dan gagasan dalam organisasi. Pada komunikasi formal, informasi ke bawah, penyampaian pesan berjalan baik, keputusan mengalir ke bawah transformasi merupakan komunikasi dari atas ke bawah, terkait tanggung jawab dan kewenangannya dalam organisasi. Manajer menggunakan komunikasi ke bawah menyampaikan informasi, mengarahkan, mengoordinasikan, memotivasi, memimpin, dan mengendalikan kegiatan. Berdasarkan penelitian yang dilakukan, maka: (1) penelitian komunikasi downward berpengaruh signifikan terhadap intensi, kekhususan, deksriptif, kemanfaatan, tepat waktu, kesiapan, kejelasan, dan validitas PT Sasa Inti. (2) Terdapat peningkatan produktivitas perusahaan berpengaruh secara signifikan terhadap produktivitas fisik dan produktivitas nilai PT Sasa Inti. (3) Komunikasi downward berpengaruh signifikan terhadap peningkatan produktivitas perusahaan pada PT Sasa Inti
\end{abstract}

Kata Kunci: Komunikasi downward, Komunikasi Bisnis, produktivitas

\section{Pendahuluan}

\section{Latar Belakang Masalah}

Era globalisasi terus terjadi dengan kecepatan tinggi menyentuh setiap aspek kehidupan manusia,dan dapat menerobos dinding geografis, kebangsaan, kebudayaan dan bahkan peradaban dunia sehingga muatan global tidak dapat dicegah lagi dan berkembang transparan terhadap perkembangan informasi. (Riyanto:2017)

Komunikasi merupakan hal yang penting dalam kehidupan dan tidak dapat dipisahkan dari organisasi. Komunikasi membantu anggota organisasi di dalamnya mencapai tujuan individu dan organisasi. Seperti 
pendapat Hovland, "Komunikasi adalah proses mengubah perilaku orang lain." (Effendy Uchjana O.,2002:10)

Komunikasi organisasi adalah pengiriman dan penerimaan pesan di dalam kelompok formal maupun informal organisasi. Tujuan komunikasi organisasi dalam rangka membentuk saling pengertian. Komunikasi organisasi mempunyai andil yang besar membangun iklim oganisasi yang berdampak membangun budaya organisasi. (Wiryanto, 2005:24)

Dalam komunikasi di perusahaan, kelancaran operasional dapat terjadi apabila hubungan yang baik tercipta antara atasan dan bawahan, pihak eksternal memiliki kesan baik terhadap perusahaan. Semua terjadi pada saat komunikasi yang dilakukan atasan terorganisir dengan baik, maka karyawan juga melakukan hal sama ketika berhadapan dengan orang yang berada di internal maupun eksternal dalam tugasnya. (Stephen P. Robbin, 2008:134)

PT Sasa Inti perusahaan pertama memproduksi MSG (Monosodium Glutamate) di Indonesia yang didirikan Rodamas tahun 1968. Nama Sasa merupakan singkatan dari "Sari Rasa" diartikan sari dari rasa dan gambaran fokus perusahaan. Faktanya, untuk orang Indonesia, Sasa berarti MSG penguat rasa, bagian bumbu dapur yang diperlukan. Kantor perwakilan Sasa di Jalan Letjen S. Parman Kav. 32-34, Slipi, Jakarta Barat. Komunikasi downward PT Sasa Inti secara rinci saat pemberian tugas bawahan. Pemberian informasi memotivasi dalam melakukan pekerjaan bagian produksi. (http://www.sasainti.com/company pro file/history.2015)

Alasan peneliti PT Sasa Inti, karena Perusahaan masih bertahan di tengah perkembangan dan persaingan bisnis industri rumah tangga yang ketat. Selain, ingin mengetahui komunikasi antara atasan dan bawahan hingga mampu bersaing dan menguasai pangsa pasar. Keberhasilan komunikasi terlihat karyawan menghasilkan produk Sasa yang semakin meningkat karena karyawan merasa bahwa pimpinan dapat menjalin komunikasi yang baik dengan mereka."

\section{Kerangka Teori}

Komunikasi tidak dapat dilepaskan dari kegiatan sehari-hari termasuk bisnis. Komunikasi bisnis berasal dua kata yakni komunikasi dan bisnis. Sebelum kita memahami lebih pengertian dari komunikasi bisnis. Komunikasi adalah proses mengirimkan dan menerima pesan, dimana komunikasi efektif terjadi jika individu mencapai pemahaman yang sama, merangsang pihak lain melakukan tindakan, dan mendorong orang berpikir dengan cara yang baru. (Caurtland L.Bovee dan Thill, John V, 2002:4)

Berbicara definisi komunikasi, tidak ada definisi yang benar atau salah karena dilihat dari manfaat untuk menjelaskan definis. Konsep definisi komunikasi, menurut Dance, komunikasi memiliki tiga dimensi yaitu (1) tingkat observasi (2) kesengajaan, (3) penilaian normatif. Sedangkan John B. Hoben, komunikasi adalah pertukaran pikiran yang diasumsikan komunikasi harus berhasil. Dalam penyampaian pesan kepada komunikan bisa menyebabkan feedback yang diterima komunikator tidak sesuai dengan yang diinginkan karena komunikasi mengacu tindakan, satu orang atau lebih, yang mengirim dan menerima pesan terdistorsi, terjadi dalam konteks, mempunyai pengaruh, dan ada kesempatan melakukan umpan balik. (Joseph A. De Vito, 1997:23)

Melihat komunikasi binis, tidak terlepas dari produksi, pembelian, penjualan, maupun pertukaran barang 
dan jasa yang melibatkan perusahaan. Aktivitas bisnis umumnya mempunyai tujuan menghasilkan laba untuk kelangsungan bagi pelaksanaan kegiatan bisnis itu. Dalam konteks yang sempit, masyarakat menghubungkan bisnis dengan usaha, organisasi yang menghasilkan dan menjual barang atau jasa. Bisnis adalah kegiatan komersial dan industrial yang menghasilkan barang dan jasa untuk meningkatkan dan mempertahankan kehidupan. Menurut Steade, bisnis bukan kegiatan yang berorientasi keuntungan melainkan pelaksanaan tanggung jawab sosial penyediaan barang dan jasa untuk meningkatkan dan menjaga taraf hidup.Keuntungan yang diperoleh dengan mengantisipasi dan memuaskan kebutuhan dan keinginan masyarakat. (Yosal Iriantara, 2009:3)

Semua organisasi disebut bisnis dimana organisasi yang menyediakan barang dan jasa untuk dijual dengan maksud mendapatkan laba. Prospek mendapatkan laba merupakan pendorong untuk memulai dan mengembangkan bisnis. (Ricky W.Griffin dan Ebert, Ronald J, 2006:135)

Definisi Komunikasi Bisnis menurut Rosenbalt adalah pertukaran opini, informasi, instruksi dan sejenisnya, baik personal ataupun nonpersonal melalui simbol, untuk mencapai tujuan perusahaan. (S. Bernard Rosenblatt. 1995:7) Menurut Himstreet dan Baty, komunikasi adalah proses pertukaran informasi antar individu melalui system yang biasa, baik dengan simbol, sinyal, maupun perilaku. (William C. Himstreet dan Wayne Murlin Bat, 2009) Dari definisi yang dikemukakan para ahli, berbedabeda dan ada beberapa kesamaan pikiran, yakni: (1) Komunikasi bisnis adalah tindakan interaksi antar dua atau lebih yang memiliki tujuan komersil. (2)
Komunikasi bisnis adalah pertukaran informasi, ide, gagasan yang bersifat mencapai serangkaian tujuan dalam mencari keuntungan baik secara verbal dan non-verbal. (3) Komunikasi bisnis adalah serangkaian kegiatan untuk melakukan pemasaran dan penjualan dengan interaksi yang dilakukan dua atau lebih dengan verbal maupun nonverbal.

\section{Komunikasi Organisasi}

Komunikasi organisasi untuk memperbaiki organisasi dalam rangka mencapai tujuan manajemen. (Arni, Muhammad, 2007:7) R. Wayne Pace dan Don F. Faules, komunikasi organisasi lebih dari sekedar yang dilakukan orang sehingga dikatakan sebagai landasan kuat bagi karier manajemen, pengembangan sumber daya manusia, komunikasi perusahaan, dan tugas yang berorientasikan dalam organisasi. (Dedy Mulyana, 2006:25)

Goldhaber mengemukakan komunikasi organisasi sebagai: "proses menciptakan dan saling menukar pesan dalam jaringan yang saling tergantung untuk mengatasi lingkungan yang selalu berubah-ubah." Definisi ini diperkuat dengan tujuh konsep kunci komunikasi organisasi (Goldhaber, 1997:267) yaitu: (1) Proses, komunikasi organisasi tercipta informasi yang ditukar terusmenerus tanpa henti karena dasarnya sistem terbuka, dinamis dan saling menukar pesan di antara anggotanya. Gejala menciptakan dan menukar informasi adalah proses komunikasi organisasi. (2) Pesan, dalam komunikasi organisasi meliputi verbal dan nonverbal. (3) Jaringan dalam komunikasi organisasi pada dasarnya terdiri satu orang yang menduduki posisi dalam organisasi. Mereka membentuk jaringan yang dipengaruhi arah dan proses pesan. Komunikasi atasan berkenaan tugas dan 
pemeliharaan seperti pengarahan, tujuan, perintah, instruksi, disiplin atau pertanyaan, dan bawahan berkenaan pengajuan pertanyaan serta umpan balik. (4) Sifat organisasi terbuka memungkinkan keadaan saling tergantung satu dengan lainnya. (5) Hubungan, dalam organisasi membuka peluang sistem kehidupan sosial yang membutuhkan manusia sebagai penghubung pesan. (6) Lingkungan, meliputi seluruh fisik dan faktor sosial yang diperhitungkan dalam keputusan individu dalam suatu sistem. (7) Ketidakpastian, terlepas dari perbedaan informasi yang tersedia dengan informasi yang diharapkan.

\section{Komunikasi Downward}

Komunikasi
merupakan bagian $\begin{array}{r}\text { downward } \\ \text { komunikasi }\end{array}$
organisasi yang merujuk pada
pertukaran informasi dan gagasan
dalam organisasi. Pada komunikasi
formal, informasi ke bawah,
penyampaian pesan berjalan baik. Dalam organisasi, keputusan mengalir ke bawah kepada yang melaksanakannya. Transformasi dari manajer merupakan komunikasi dari atas ke bawah. Aliran komunikasi dari manajer terkait tanggung jawab dan kewenangannya dalam organisasi. Manajer yang menggunakan komunikasi ke bawah memiliki tujuan menyampaikan informasi, mengarahkan, mengoordinasikan, memotivasi, memimpin, dan mengendalikan kegiatan.(Wahdi Mohammad, 2011: 9 - 10)

Menurut Katz dan Khan, komunikasi ke bawah memiliki lima tujuan yaitu: (1) memberikan pengarahan kerja tertentu, (2) memberikan informasi pekerjaan harus dilaksanakan, (3) memberikan informasi prosedur dan praktek organisasional, (4) memberikan umpan balik pelaksanaan kerja kepada karyawan, dan (5) menyajikan informasi aspek ideologi organisasi menanamkan tujuan yang ingin dicapai. (Djoko Purwanto, 2003:98)

Sebuah metode harus dipilih atasan dalam menyampaikan informasi ke bawahan. Menurut Level dan Galle, ada enam kriteria yang digunakan memilih metode penyampaian informasi kepada karyawan, (Wayne Pace dan Don F.Faules, 1998:58) yaitu: (1) Ketersediaan: metode dalam perusahaan digunakan,setelah menginventariskan metode, perusahaan memutuskan metode yang digunakan dan efektif. (2) Biaya: metode murah cenderung dipilih untuk informasi rutin dan tidak mendesak. Apabila diperlukan yang tidak rutin dan mendesak maka menggunakan metode yang mahal tetapi cepat digunakan. (3) Pengaruh: metode yang tampaknya memberi kesan besar dipilih dari pada metode yang baku. (4) Relevansi: metode yang paling relevan dengan tujuan yang dicapai sering dipilih. (5) Respon: metode yang dipilih dipengaruhi ketentuan apakah respons khusus informasi. (6) Keahlian: metode kemampuan pengirim dan penerima untuk pemahaman metode yang di luar kemampuan komunikator.

Bersandar perbedaan otoritas, yang diterjemahkan menjadi perbedaan status, hak, dan pengawasan adalah hubungan atasan dan bawahan. Hubungan yang paling umum dan penting dalam perusahaan secara efektif dan efisien. Apabila hubungan antara atasan dan bawahan terjalin baik maka ada peningkatan produktivitas dalam perusahaan. Menurut Jablin, sembilan kategori masalah komunikasi atasan dan bawahan (FM.Jablin dan Linda, 2001), yaitu: (1) Pola interaksi, dominan terjadi adalah tatap muka adanya interaksi pekerjaan. Atasan memungkinkan memulai interaksi daripada bawahan. Kepuasan kerja bawahan berkolerasi positif apabila hubungan antara atasan 
dan bawahan terjalin, atasan sebagai penghubung produksi dibandingkan dengan pemeliharaan. (2) Keterbukaan, bawahan puas dengan pekerjaannya apabila adanya keterbukaan atasan dan bawahan. Keterbukaan komunikasi berhubungan kinerja organisasi. Kesediaan atasan dan bawahan untuk melakukan pembicaraan yang terkait perusahaan merupakan kunci komunikasi. (3) Distorsi komunikasi seringkali terjadi, dalam hubungan atasan dan bawahan apabila tidak mempercayai, akan mengungkapkan kepada orang lain dan terlibat perilaku komunikatif yang menghindar. Bawahan cenderung mengabaikan komentar kritis dalam interkasi dengan atasan karena bawahan kurang bebas berkomunikasi dengan atasannya. (4) Pengaruh ke atas, bawahan yang memandang atasan sebagai pengaruh, mempunyai keinginan berinteraksi dengan atasan, memberikan kepercayaan atasan dan menganggap informasi yang diterima dari atasan adalah kecermatan tinggi. Keyakinan dan kepercayaan bawahan kepada atasan berkaitan keberhasilan atasan dalam interaksinya dengan manajemen. (5) Jarak informasi semantic, yang serius antara atasan dan bawahan. (6) Atasan efektif versus atasan tidak efektif. Atasan yang efektif cenderung berbicara dalam pertemuan, mampu menerangkan instruksi dan kebijakan, suka berbincang dengan bawahan. Selain itu, atasan yang efektif cenderung menjadi pendengar, empatik, memberi respon penuh pengertian atas pertanyaan, serta mendengarkan saran bawahan, lebih sering bertanya daripada memberitahu, lebih peka kebutuhan karyawan, dan cenderung lebih terbuka dalam menyampaikan informasi. Keefektifan atasan bergantung faktorfaktor seperti struktur pekerjaan, hubungan baik antara atasan dan bawahan serta kekuasaan posisi atasan. (7) Sifat-sifat pribadi, bawahan yang menyukai pengawasan internal memandang atasan sebagai pribadi bijaksana sedangkan bawahan yang menyukai pengawasan eksternal memandang atasan sebagai pribadi partisipatif. Berbanding dengan bawahan, atasan yang menyukai pengawasan internal menggunakan bujukan untuk memperoleh kerjasama dengan bawahan, sedangkan yang menyukai pengawasan eksternal cenderung menggunakan kekuasaan yang memaksa. (8) Umpan balik, Kemampuan bawahan memberikan umpan balik lebih besar jika bawahan diberitahu yang perlu dikerjakan oleh atasan. Umpan balik positif atasan cenderung membuat atasan berorientasi bekerja dan kinerja atasan lebih baik. (9) Pengaruh variabel organisasi sistemik pada kualitas komunikasi atasan dan bawahan.

\section{Faktor yang mempengaruhi komunikasi atasan bawahan}

Arus komunikasi atasan kepada bawahan tidaklah selalu lancar, tetapi dipengaruhi berbagai faktor antara lain: (1) Keterbukaan, kurangnya sifat terbuka pimpinan dan karyawan menyebabkan tidak mau menyampaikan pesan dan gangguan. Umumnya pimpinan tidak memperhatikan arus komunikasi ke bawah. Pimpinan mau memberikan informasi ke bawah bila merasa pesan penting bagi tugas. (2) Kepercayaan pesan tulisan, kebanyakan pimpinan percaya pesan tulisan dan metode difusi yang menggunakan alat elektronik daripada pesan yang disampaikan secara lisan dan tatap muka. Hal ini menjadikan pimpinan menyampaikan pesan secara tertulis berupa buletin, booklet, dan film sebagai pengganti kontak personal tatap muka antara 
atasan dan bawahan. (3) Pesan yang berlebihan, banyaknya pesan yang dikirimkan secara tertulis maka karyawan dibebani dengan memo, buletin, surat pengumuman, majalah, dan pernyataan kebijaksanaan sehingga banyak pesan yang harus dibaca Reaksi karyawan terhadap pesan biasanya tidak membacanya. Banyak karyawan hanya membaca pesan yang penting bagi dirinya dan lain dibiarkan tanpa dibaca. (4) Ketepatan waktu, pengiriman pesan mempengaruhi komunikasi ke bawah. Pimpinan hendaklah mempertimbangkan saat yang tepat bagi pengiriman pesan dan dampak yang potensial kepada karyawan. Pesan seharusnya dikirimkan ke bawah dimana saling menguntungkan antara pimpinan dan karyawan. Penyaringan, Pesan yang dikirimkan kepada bawahan tidaklah semua diterima, tetapi disaring mana yang diperlukan. Penyaringan pesan ini disebabkan oleh faktor perbedaan persepsi di antara karyawan dan pimpinan. (Miftah Thoha, 2005:48)

\section{Dimensi Komunikasi Atasan Bawahan}

Komunikasi yangef ektifdianalisis menggunakan dimensi berikut: (1) Intensi, komunikasi efektif jika langsung menyempurnakan pelaksanaan pekerjaan dan menjadikan pegawai sebagai harta milik yang berharga. Komunikasi tidak bersifat hal pribadi, hanya diarahkan pada aspek pekerjaan pegawai. (2) Kekhususan, komunikasi efektif untuk membekali penerima dengan informasi khusus sehingga yang seharusnya dikerjakan benar. Komunikasi yang tidak efektif jikalau bersifat umum dan meninggalkan tanda tanya bagi penerimanya.(3) Deskriptif, komunikasi efektif dilakukan lebih bersifat bersifat evaluatif. Berarti perlu penjelasan pelaksanaan pekerjaan, kepada karyawan apa yang dikerjakan dalam bahasa objektif, dan tidak dikemukakan hal yang bersifat penilaian. (4) Kemanfaatan, karakteristik ini mengemukakan agar komunikasi mengandung informasi yang dipergunakan karyawan untuk memperbaiki dan menyempurnakan pekerjaannya dengan petunjuk untuk menambah kecakapannya. (5) Tepat waktu, komunikasi efektif jika terdapat pertimbangan yang memperhitungkan faktor waktu yang tepat. (6) Kesiapan, para karyawan hendaknya mempunyai kesiapan untuk menerima informasi. (7) Kejelasan, komunikasi dapat dimengerti secara jelas oleh penerima. Cara yang baik mengetahui hal ini adalah membuktikan langsung meminta kepada penerima untuk menyatakan pokok apa yang telah dibicarakan bersama. Cara lain dengan melihat ekspresi salah satu indikator adanya pengertian. (8) Validitas, Komunikasi hendaknya dapat dipercaya dan sah, memberikan informasi benar dan tidak membiarkan karyawan memperbaiki kesalahan dengan informasi salah.

\section{Produktivitas}

Dalam bisnis semakin dituntut mengutamakan produktivitas organisasi dinilai dari produktivitasya. Semakin tinggi produktivitasnya, maka produk hasil dari usaha kerja mempunyai kualitas yang kompetitif di pasaran. Menurut Russel, produktivitas menunjukkan rasio keluaran terhadap masukan. Keluaran didefinisikan sebagai hasil akhir dari produksi. Sedangkan masukan adalah tenaga kerja, modal, dan sumber daya industri. (R.S. Russell dan Bernard WT,1995: 253)

Dikatakan produktivitas adalah perbandingan antara hasil dari pekerjaan dengan pengorbanan yang dikeluarkan, dimana produktivitas adalah kemampuan memperoleh 
manfaat dari sarana dan prasarana yang tersedia dengan menghasilkan output yang optimal bahkan maksimal. (Sondang P. Siagian, 2002:45)

Selain ratio output dengan input, ahli lain mengartikan produktivitas dengan melihatnya efektifitas dan efisiensi, produktivitas suatu organisasi dikatakan produktif jika organisasi itu mencapai tujuan, dan mencapainya dengan upaya transformasi input menjadi output dengan biaya paling rendah. (Stephen P., Robbins, 2006:260) Definisi produktivitas memiliki dua dimensi, yaitu: efektivitas, dimensi yang berkaitan dengan optimalisasi ketercapaian rencana kerja, dilihat dari aspek kualitas, kuantitas, durasi penyelesaian pekerjaann, dan ketepatan pengalokasian sumber daya. (b) efisiensi pada dimensi ini, pengukuran produktivitas pada realisasi penggunaan sumber daya dan bagaimana pekerjaan dilaksanakan, apakah terjadi pemborosan, penyalahgunaan, atau penyimpangan sumber daya yang menimbulkan ketidaktercapaian target produk.

Faktor-faktor

mempengaruhi

digolongkan menjadi tiga kelompok, yaitu: (1) Kualitas dan kemampuan fisik pekerja, faktor ini dipengaruhi tingkat pendidikan, latihan, motivasi kerja, etos kerja, mental, dan kemampuan fisik pekerja yang bersangkutan. Semakin tinggi tingkat pendidikan maka semakin tinggi produktivitas kerjanya. (2) Sarana pendukung kerja, untuk meningkatkan produktivitas kerja mencakup lingkungan kerja dan kesejahteraan karyawan. (a) Mencakup lingkungan kerja, teknologi dan produksi, sarana dan peralatan produksi yang digunakan, tingkat keselamatan dan kesehatan kerja serta lingkungan kerja. (b) Mencakup kesejahteraan karyawan, yang terjamin dalam sistem pengupahan dan jaminan sosial, serta jaminan kelangsungan kerja. (3) Prasarana, kemampuan manajemen menggunakan sumber secara maksimal dan menciptakan sistem kerja optimal, akan menentukan tinggi rendahnya produktivitas kerja. Peranan manajemen sangat penting dan strategis untuk peningkatan produktivitas, yaitu mengkombinasikan dan mendayagunakan sarana produktivitas, menerapkan fungsi manajemen, menciptakan sistem kerja dan pembagian produksi, menempatkan orang yang tepat dan pekerjaan tepat, serta menciptakan kondisi dan lingkungan kerja yang nyaman. (Simanjuntak, Payaman J.,2003:30) Menurut Sinungan, produktivitas dipengaruhi faktor: (1) Kemauan Kerja, merupakan dorongan dalam diri, untuk meningkatkan produktivitas. Kemauan kerja dari karyawan dilihat besarnya kontribusi yang diberikan kepada perusahaan seperti bekerja sungguh-sungguh, adanya kesadaran mengikuti peraturan, instruksi, dan kegiatan yang dilakukan perusahaan.(2) Kemampuan kerja, Pekerjaan yang dilakukan harus sesuai kemampuan dan ketrampilan karyawan. Produktivitas meningkat apabila karyawan mampu menjalankan bekerja baik. (3) Lingkungan kerja, Salah satu faktor yang berpengaruh adalah lingkungan kerja. Lingkungan kerja mendukung pekerjaan yang dilakukan karyawan. (4) Kompensasi, adalah sesuatu yang diterima karyawan sebagai pengganti kontribusi jasa yang telah diberikan pada perusahaan. Kompensasi merupakan balas jasa yang diberikan perusahaan baik secara langsung maupun tidak langsung. (5) Jaminan sosial yang memadai, jaminan sosial yang diberikan perusahaan membuat karyawan bekerja produktif karena 
merasa perusahaan memperhatikan keselamatan dan kesehatan karyawan sewaktu bekerja. (6). Hubungan kerja yang harmonis, terjalin antara atasan, bawahan, dan rekan kerja sangat penting untuk menciptakan situasi kerja yang nyaman.(Sinungan, Muchdarsyah, 2005:15)

Organisasi disebut produktif jika mencapai tujuannya melalui proses transformasi input ke output dengan biaya terendah. Dalam produktivitas terdapat dua aspek yaitu efektifitas dan efisiensi. Penjualan dikatan efektif apabila mencapai target penjualan, tetapi produktivitas perusahaan tergantung apakah perusahaan tersebut mampu mencapai target dengan efisien. Peningkatan produktivitas dapat berpengaruh terhadap: (1) meningkatkan laba perusahaan, (2) peningkatan pendapatan karyawan, (3) Meningkatkan Pendapatan negara melalui pajak,(4) Harga Pokok menjadi lebih rendah (5) Harga jual dapat diturunkan (6)Hasil Produksi menjadi lebih besar (7)lebih banyak konsumen yang menikmati (8) Perusahaan penghasil menjadi kompetitif (9) meningkatkan kemakmuran (Stephen P.Robbins dan Coulter, 2005:45)

\section{Hubungan Komunikasi Downward dengan Peningkatan Produktivitas}

$$
\begin{array}{cc}
\text { Tiffin dan Cormick } \\
\text { mengatakan bahwa faktor }
\end{array}
$$$$
\text { yang mempengaruhi produktivitas }
$$
dapat disimpulkan menjadi dua, yaitu: (1) Faktor yang ada pada diri individu, yaitu umur, emosional, keadaan fisik, kelemahan, dan motivasi. (2) Faktor yang ada di luar individu, yaitu kondisi fisik seperti penerangan, waktu, istirahat, lama kerja, upah, bentuk organisasi, lingkungan sosial, dan keluarga. (McCormick dan Tiffin, 2003:226)
Berkembangnya

bisnis menentukan produktivitas dilihat faktor kuantitas tetapi juga faktor kualitasnya. Produktivitas dibagi tiga tingkatan yaitu individu, kelompok, dan organisasi, dalam organisasi bisnis dapat diukur produktivitasnya. Alma menguraikan tiga ukuran produktivitas yang dipertimbangkan dalam mengelola organisasi yaitu: (1) Untuk tujuan strategi, apakah organisasi sudah benar sesuai dengan apa yang digariskan. (2) Efektivitas, sampai tujuan itu dicapai dalam arti kuantitas dan kualitas.(3) Efisiensi, perbandingan output dibagi input, dimana pengukuran output termasuk di dalamnya kuantitas dan kualitas. (Buchori Alma, 2006:70-71)

Produktivitas merupakan hal penting bagi karyawan di perusahaan. Dengan produktivitas kerja diharapkan pekerjaan terlaksana secara efisien dan efektif. Menurut (Tjutju Yuniarsih dan Suwatno:2008) mengemukakan produktivitas diukur dengan dua dimensi yaitu: (1) Produktivitas Fisik, diukur dari aspek kuantitas produk yang dihasilkan, kualitas produk yang dihasilkan. Kuantitas merupakan volume dari produk atau jasa yang dihasilkan. Goestsch dan Davis (Tjiptono, Fandy, 2008:82) mengemukakan bahwa kualitas merupakan suatu kondisi dinamis yang berhubungan dengan produk, jasa, sumber daya manusia, proses, dan lingkungan yang memenuhi atau melebihi harapan. (2) Produktivitas Nilai diukur dari nilai-nilai kemampuan, sikap, disiplin, motivasi, dan komitmen terhadap pekerjaan. (a) Nilai-nilai kemampuan, Gordon, mengemukakan nilai-nilai kemampuan merupakan nilai yang dimiliki oleh individu untuk melaksanakan tugas atau pekerjaan yang dibebankan kepadanya. (Sutrisno, Edy,2009:223) (b) Sikap, Sikap merupakan perasaan atau reaksi terhadap suatu rangsangan yang datang 
dari luar. (c) Disiplin, Singodimedjo dalam Sutrisno mengemukakan, disiplin adalah sikap kesediaan dan kerelaan seseorang untuk mematuhi dan menaati normanorma peraturan yang berlaku di sekitarnya. Disiplin yang baik pada karyawan akan mempercepat tujuan perusahaan, sedangkan disiplin yang merosot akan memperlambat pencapaian tujuan. (Sutrisno, Edy, 2009:90) (d) Motivasi, Motivasi merupakan proses untuk mempengaruhi agar mau melakukan sesuatu. Produktivitas atau prestasi seseorang tergantung pada motivasi orang tersebut terhadap pekerjaannya. (e) Komitmen terhadap pekerjaan, Hasibuan mengemukakan komitmen karyawan terhadap pekerjaannya dicerminkan oleh kesediaan karyawan menjaga dan membela organisasi di dalam maupun di luar dari orang yang tidak bertanggung jawab. (Sutrisno, Edy, 2009:90)

Teori yang menjadi penguat adalah teori empat sistem Teori empat sistem adalah teori komunikasi yang mengkaji hubungan antarmanusia melalui hasil dari produksinya dilihat dari kacamata manajemen. (Littlejohn, Stephen W., dan Karen A. Foss.2002) Menurut Luthans, struktur peniti penyambung cenderung menekankan dan memudahkan apa yang seharusnya terjadi dalam struktur klasik dan birokratik. (Luthans, Fred, 2006:54) Ciri organisasi berstruktur peniti penyambung adalah lambatnya tindakan kelompok, harus diimbangi dengan memanfaatkan partisipasi positif. Apabila seseorang memperhatikan dan memelihara pekerjanya dengan baik maka operasional perusahaan membaik. Fungsi manajemen berlangsung dalam empat sistem yaitu: (1)Sistem Otoritatif dan Eksploitif, sistem yang penuh tekanan dan otoriter, segala sesuatu diperintahkan dan tidak memerlukan umpan balik, atasan tidak memiliki kepercayaan terhadap bawahan dan bawahan tidak memiliki kewenangan mendiskusikan pekerjaannya dengan atasan. Akibat konsep ini adalah ketakutan, ancaman dan hukuman jika tidak selesai. Proses komunikasi lebih banyak dari atas ke bawah. (2) Sistem Otoritatif dan Benevolent, sistem lebih lunak dari otoriter dimana manajer lebih sensitif terhadap kebutuhan karyawan. Manajemen berkenan untuk percaya bawahan dalam hubungan atasan dan bawahan, keputusan ada di atas namun ada kesempatan bawahan untuk turut memberikan masukan atas keputusan itu. (3) Sistem Konsultatif, sistem konsultatif pimpinan mencari masukan. Pada sistem ini, karyawan bebas berhubungan dan berdiskusi dengan atasan dan interaksi nyata. Keputusan di tangan atasan, namun bawahan memiliki andil dalam keputusan.(4) Sistem Partisipatif, sistem partisipan dimana bawahan berpartisipasi aktif dalam membuat keputusan. Di sini, manajemen percaya sepenuhnya pada bawahan dan dapat membuat keputusan. Alur informasi ke atas, ke bawah, dan menyilang. Komunikasi ke bawah pada umumnya diterima, jika tidak dapat dipastikan dan diperbolehkan ada diskusi antara bawahan dan atasan. Interaksi dalam sistem terbangun, komunikasi ke atas umumnya akurat dan manajer menanggapi umpan balik. Motivasi kerja dikembangkan dengan partisipasi kuat dalam pengambilan keputusan, penetapan tujuan, dan penilaian.

Teori empat sistem oleh Rensis Likert memiliki variabel yang digunakan untuk menilai keempat sistem yang diterapkan Likert. Dimensi terdiri dari kepercayaan, motivasi, dan interaksi. Dimensi tersebut mewakili dimensi pada kedua variabel yakni variabel X komunikasi downward dan 
variabel $\mathrm{Y}$ peningkatan produktivitas perusahaan. Dimensi kepercayaan dalam komunikasi downward terdapat dalam kekhususan, deskriptif, kemanfaatan, dan validitas sedangkan dalam peningkatan produktivitas terdapat dalam kuantitas dan kualitas. Dimensi motivasi dalam komunikasi downward ditunjukkan dalam tepat waktu dan intensi sedangkan dalam peningkatan produktivitas terdapat dalam sikap, disiplin, motivasi dan komitmen terhadap pekerjaan. Dimensi interaksi dalam komunikasi downward terdapat dalam kesiapan dan kejelasan sedangkan dalam peningkatan produktivitas terdapat dalam nilai-nilai kemampuan. Karena itu, peneliti menggunakan dimensi sesuai teori empat sistem dalam menganalisis hubungan dilihat dari manajemen melalui hasil produksinya. Teori ini sesuai dengan penelitian untuk melihat komunikasi downward yang mempengaruhi produktivitas perusahaan.

\section{Hubungan Komunikasi Bisnis dengan Komunikasi Downward}

Hubungan antara komunikasi bisnis dengan komunikasi downward terdapat dalam konsep komunikasi bisnis dengan melihat tiga karakteristik pesan bisnis yang efektif (Bovee, Courtland L.,\& John V. Thill, 2003) yaitu: (1) Purposeful, Setiap pesan haruslah memiliki maksud dan tujuan yang spesifik, untuk memberi informasi, memecahkan masalah atau permintaan untuk melakukan sesuatu dalam rangka mencapai tujuan. Kaitannya dengan karakteristik pesan dalam komunikasi bisnis dan komunikasi downward, menunjukkan pesan dalam komunikasi harus memiliki maksud dan tujuan yang spesifik dan jelas sehingga dapat memberikan solusi masalah dan mencapai tujuannya. (2) Audience-centered, Pesan bisnis membantu audience dalam memahami tujuan pesan. Oleh karena itu, pesan haruslah berorientasi kepada audience memahami kebutuhannya, pandangannya, dan latar belakangnya. Kaitan dalam komunikasi bisnis dengan komunikasi downward terlihat jika atasan memberikan informasi kepada bawahan harus mampu membantu bawahan untuk memahami tujuan yang ingin dicapai dengan melihat apakah bawahan siap menerima informasi dan memahami kebutuhan serta memperbolehkan bawahannya mengeluarkan pendapat dan persepsinya terhadap pesan. (3) Concise, Pesan bisnis harus menghormati waktu setiap orang dengan memberikan informasi secara jelas dan efisien. Dalam komunikasi downward berkaitan dengan karakteristik pesan bisnis yang dikemukakan Bovee jika pesan harus menghormati waktu bawahan. Atasan harus memperhitungkan apakah karyawan telah siap jika diberi informasi untuk pelaksanaan pekerjaan sehingga pemberian informasi menjadi jelas dan efisien. Pemberian informasi yang jelas serta efisien dalam hal waktu pelaksanaan pekerjaan menjadi penting untuk dilihat oleh atasan karena ketika bawahan siap menerima informasi maka pesan yang disampaikan juga memiliki kejelasan.

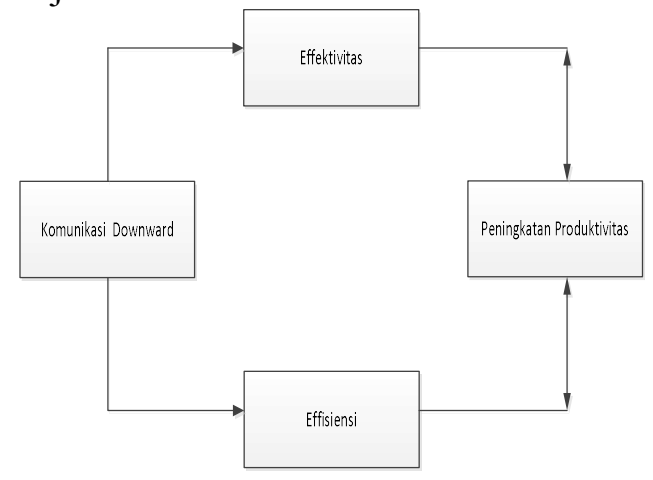

Gambar 1. Bagan Hubungan

Komunikasi Bisnis dengan Komunikasi Downward 


\section{Metodologi Penelitian}

Pendekatan penelitian ini adalah kuantitatif, dari sejumlah teori, yang didedukasikan menjadi hipotesa dan asumsi kerangka pemikiran yang dijabarkan dalam model analisa, yang terdiri variabel yang mengarah operasionalisasi konsep. Penelitian kuantitatif menuntun peneliti menemukan masalah penelitian, menemukan hipotesis, menemukan konsep, menemukan metodologi, dan menemukan analisi-analisis data. (Bungin, Burhan H.M, 2006:25)

Dalam penelitian dan sebagai bahan kelengkapan penelitian, berupa data dengan menggunakan: Kuesioer dan studi kepustakaan. Kuesioner berupa data primer yang diperoleh dengan menyebarkan daftar pertanyaan kepada responden penelitian, sedang studi kepustakaan untuk mencari berbagai literatur, hasil kajian atau studi yang berhubungan dengan penelitian yang dilakukan. Ada berbagai jenis sumber pustaka yang dapat dimanfaatkan, seperti sumber tertulis yaitu buku teks, surat kabar, jurnal, dan sebagainya. (Martono, Nanang, 2010:42) Tujuan dari studi kepustakaan adalah untuk menghubungkan peneliti dengan konteks yang lebih luas, terutama bahan buku, internet, dan hasil riset yang berkenaan, komunikasi downward, company profile, dan peningkatan produktivitas.

\section{Populasi}

Populasi adalah wilayah generalisasi terdiri atas objek atau subjek yang mempunyai kualitas dan karakteristik tertentu yang ditetapkan oleh peneliti untuk dipelajari ditarik kesimpulannya. (Sugiyono, 2008:80) Menurut Hamidi, populasi adalah keseluruhan analisis yang diteliti, individu responden. Unit analisis penelitian komunikasi berupa individu, kelompok individu, dan teks media massa. (Hamidi,2007:126)

Populasi pada penelitian ini adalah manajer dan karyawan bagian produksi PT Sasa Inti, Slipi, Jakarta Barat berjumlah 172 orang, sehingga atasan dan bawahan dapat mempengaruhi peningkatan produktivitas perusahaan. Karena diketahui bahwa komunikasi bagian terpenting dalam bisnis terutama komunikasi yang dilakukan antara atasan dan bawahan yang dapat mempengaruhi produktivitas dengan komunikasi yang baik yang diterapkan atasan.

Menurut Ruslan, untuk kepraktisan, peneliti akan meneliti sebagian elemen populasi yang dianggap "sampel" dalam penelitian dan benar-benar mewakili populasi yang diteliti. (Ruslan, Rosady, 2006: 140) Sampel adalah sebagian populasi yang diambil sebagai sumber data dan mewakili seluruh populasi. (Arikunto, Suharsimi, 2002:117)

Suatu sampel yang baik
memenuhi persyaratan mengenai
,ukuran adalah cukup memadai yang
tergantung sifat populasi dan tujuan
penelitian. Semakin besar sampel
diambil, maka akan semakin kecil
kemungkinan salah dalam menarik
kesimpulan.
(Ruslan, Rosady,2006:149) Dari beberapa pendapat ditarik kesimpulan bahwa sampel adalah bagian dari populasi yang memiliki ciri atau keadaan yang diteliti.

Untuk mendapatkan jumlah
sampel yang diteliti, peneliti menggunakan rumus Taro Yamane (Riduwan dan Sunarto, 2007:65):

$$
\mathrm{N}=\frac{N}{N d^{2}+1}
$$


Teknik ampling untuk menentukan sampel yang digunakan dalam penelitian, terdapat terbagai teknik sampling yang digunakan. (Sugiyono, 2009:81). Teknik sampling adalah cara menentukan sampel yang sesuai dengan ukuran sampel yang dijadikan sumber data sebenarnya dengan memperhatikan sifat dan penyebaran populasi agar diperoleh sampel yang benar mewakili populasi. (Nawawi, Hadari, 2003:152)

\subsection{Uji Validitas}

Validitas merupakan derajat ketepatan antara data yang sesungguhnya terjadi pada penelitian dengan data yang dapat dilaporkan. Validitas adalah ukuran yang menunjukkan tingkat kevalidan instrumen. Uji validitas pada instrumen ini menggunakan teknik analisis faktor. Analisis faktor adalah teknik statistik untuk mengidentifikasikan jumlah faktor yang relatif kecil yang digunkan untuk menggambarkan hubungan antara variabel yang saling berhubungan. (Sugiyono,2009:114) Analisis faktor menghasilkan tabel dimana baris menunjukkan variabel indikator mentah yang diamati dan kolom menunjukkan faktor yang menjelaskan sebanyak mungkin perbedaan di dalam variabel ini. Menurut Guilford, kriteria interpretasi koefisien validitas sebagai berikut (Guilford, JP, 1995:145):

Tabel 1. Klasifikasi Interpretasi Koefisien Validitas

\begin{tabular}{|c|c|}
\hline Nilai $\boldsymbol{r}$ & Interpretasi \\
\hline $0,81-1,00$ & Sangat Tinggi \\
\hline $0,61-0,80$ & Tinggi \\
\hline $0,41-0,60$ & Cukup \\
\hline $0,21-0,40$ & Rendah \\
\hline $0,00-0,20$ & Sangat Rendah \\
\hline
\end{tabular}

\section{Uji Reliabilitas}

Reliabilitas adalah sejauh mana hasil suatu pengukuran dapat dipercaya dan dilakukan dalam beberapa kali pengukuran terhadap kelompok subjek yang sama diperoleh hasil relatif sama. Reliabilitas adalah ukuran yang menunjukkan konsistensi alat ukur dalam mengukur gejala yang sama di lain kesempatan walaupun digunakan berulang kali. Reliabilitas mengandung arti bahwa alat ukur tersebut stabil, dapat diandalkan dan tetap (Kriyantono, Rakhmat, 2006:140)

Uji reliabilitas menunjukan pada suatu pengertian bahwa suatu instrumen cukup dapat dipercaya untuk digunakan sebagai alat pengumpul data karena instrumen tersebut sudah baik. Intrumen yang sudah dapat dipercaya akan menghasilkan data yang dapat dipercaya juga. Reliabilitas menunjukan pada tingkat keterhandalan sesuatu. (Arikunto, Suharsimi, 2002:154)

Dalam menguji reliabilitas, peneliti menggunakan metode Cofficient Cronbach's Alpha, yaitu ratarata dari koefisien korelasi belah dua yang mungkin dibuat alat ukur. Uji reliabilitas dalam penelitian dilakukan one shot atau pengukuran sekali saja, yakni hanya dengan sekali test kemudian hasilnya dibandingkan dengan mengukur korelasi antar jawaban pertanyaan. Analisisnya sendiri menggunakan Cronbach's Alpha ( $\alpha)$. Menurut Nunnally suatu variabel, dikatakan reliable jika memiliki nilai Cronbach's Alpha $(\alpha)>$ 0,60 . Tabel 2, merupakan standarisasi pengukuran reliabilitas melalui Cronbach's Alpha (Santoso, 2000:110) 
Tabel 2. Tabel standarisasi pengukuran reliabilitas

\begin{tabular}{|c|c|}
\hline $\begin{array}{l}\text { NILAI } \\
\text { ALPHA }\end{array}$ & KETERANGAN \\
\hline $\begin{array}{r}0,0 \\
<\alpha \leq 0,2 \\
\end{array}$ & $\begin{array}{l}\text { Reliabilitas data } \\
\text { buruk }\end{array}$ \\
\hline $\begin{array}{r}0,2 \\
<\alpha \leq 0,4\end{array}$ & $\begin{array}{l}\text { Reliabilitas data } \\
\text { kurang }\end{array}$ \\
\hline $\begin{array}{r}0,4 \\
<\alpha \leq 0,6 \\
\end{array}$ & $\begin{array}{l}\text { Reliabilitas data } \\
\text { cukup }\end{array}$ \\
\hline $\begin{array}{r}0,6 \\
<\alpha \leq 0,8 \\
\end{array}$ & $\begin{array}{ll}\text { baik } & \text { Reliabilitas data } \\
\end{array}$ \\
\hline $\begin{array}{r}0,8 \\
<\alpha \leq 1,00\end{array}$ & $\begin{array}{l}\text { Reliabilitas data } \\
\text { sangat baik }\end{array}$ \\
\hline
\end{tabular}

\section{Teknik Analisis Data}

Menurut Patton dalam Lexy J. Moleong menjelaskan bahwa analisis data adalah proses mengatur urutan data, mengorganisasikannya ke dalam pola, kategori, dan satuan uraian dasar. (Moloeng, Lexy J,2002:103) Data dikumpulkan melalui kuesioner yang disajikan dalam bentuk tabel distribusi frekuensi dan dilakukan pembahasan dengan menghubungkannya dengan data yang diperoleh dan mengaitkannya dengan teori-teori yang digunakan.

Untuk mengelola data kuantitatif, digunakan skala Likert. Skala Likert terdiri sejumlah pertanyaan yang semuanya menunjukkan sikap terhadap objek tertentu atau menunjukkan ciri tertentu yang akan diukur. Untuk setiap pertanyaan, disediakan sejumlah alternatif tanggapan yang berjenjang. (Soehartono, Irawan,2002:77) Cara pemberian nilai untuk tanggapan yang diberikan responden terhadap pertanyaan yang tersedia di kuesioner adalah dengan memberikan nilai dari setiap jawaban yang telah ditentukan. Regresi adalah suatu proses memperkirakan secara sistematis tentang apa yang paling mungkin terjadi di masa yang akan datang berdasarkan informasi masa lalu dan masa sekarang yang dimiliki agar dapat memperkirakan perubahan. (Riduwan, 2004:145) Uji regresi bertujuan untuk menguji pengaruh antara satu variabel terhadap variabel lain. Regresi yang memiliki satu variabel dependen dan satu variabel independen disebut regresi linier sederhana, sedangkan dari analisis regresi linier ganda merupakan analisis hubungan beberapa variabel independen dengan satu variabel dependen yang berguna untuk meramalkan nilai variabel terikat $(\mathrm{Y})$ apabila variabel bebas $(\mathrm{X})$ minimal dua atau lebih. (Bhuono, Nugroho, 2005:43) Oleh karena itu, dalam penelitian ini digunakan analisis regresi linier sederhana.

\section{Hasil dan Pembahasan}

Uji asumsi klasik merupakan tahap awal yang digunakan sebelum analisis regresi linear. (Imam Ghozali, 2011:105) Pengujian ini untuk memberikan kepastian bahwa persamaan regresi yang didapatkan memiliki ketepatan dalam estimasi, tidak bias, dan konsisten. Dalam penelitian ini digunakan empat uji asumsi klasik yaitu uji normalitas, uji linearitas, uji homogenitas, dan uji heteroskedastisitas. 
Tabel 3. One-Sample KolmogorovSmirnov Test

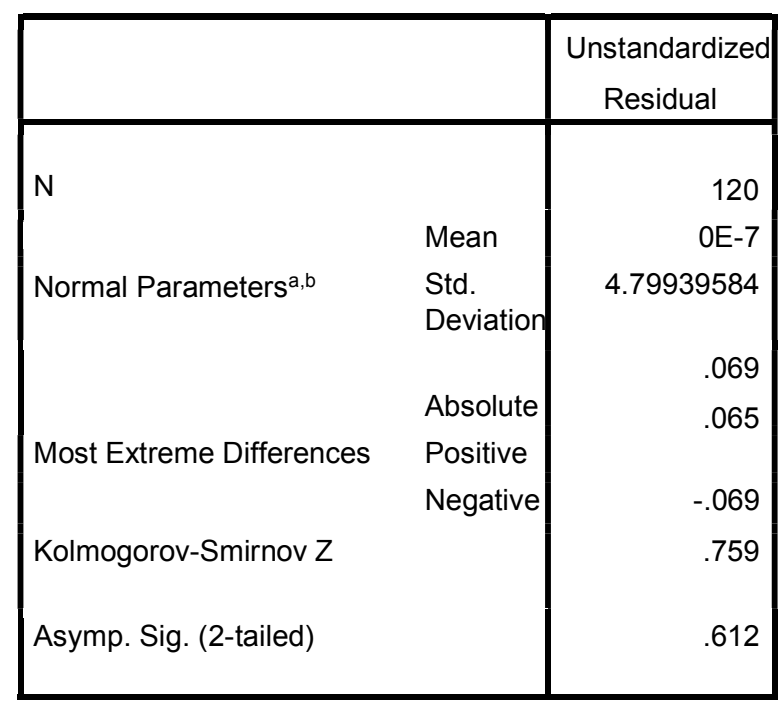

1. Test distribution is Normal.

2. Calculated from data.

Dalam uji normalitas, jika signifikansi lebih besar dari 0,05 maka data tersebut berdistribusi normal. Sebaliknya, jika taraf signifikansi lebih kecil dari 0,05 maka data tersebut tidak berdistribusi normal. (Sumanto, 2014: 149) Berdasarkan tabel 3, diketahui nilai uji normalitas Kolmogorov Smirnov penelitian ini adalah sebesar 0,612. Dengan hasil tersebut, maka dapat ditarik kesimpulan bahwa penelitian ini berdistribusi normal karena signifikansi lebih dari 0,05.

Tabel 4. NOVA Table

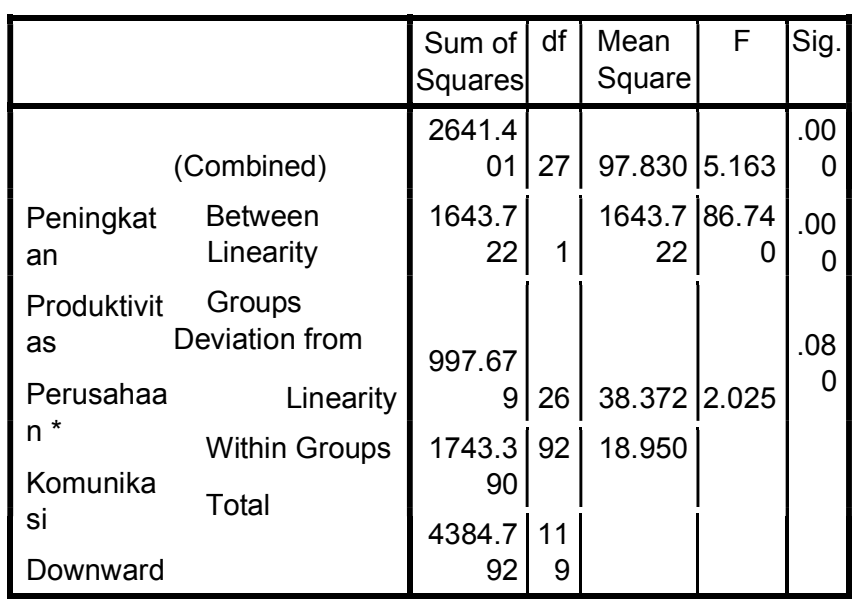

Berdasarkan tabel 4, nilai signifikansi sebesar 0,080. Dalam uji linearitas terdapat asumsi pengambilan keputusan, jika nilai signifikansi lebih besar dari 0,05 maka terdapat hubungan linear secara signifikan antara variabel, Komunikasi Downward dengan variabel Peningkatan Produktivitas Perusahaan. Sebaliknya, jika nilai signifikansi lebih kecil dari 0,05 maka tidak terdapat hubungan linear secara signifikan antara variabel independen dengan variabel dependen. Berdasarkan hasil di tabel 4, maka dapat diambil keputusan bahwa terdapat hubungan linear secara signifikan antara variabel komunikasi downward dengan variabel peningkatan produktivitas perusahaan.

\section{Tabel 5. Test of Homogeneity of} Variances

\begin{tabular}{|r|r|r|r|}
\hline $\begin{array}{l}\text { Levene } \\
\text { Statistic }\end{array}$ & \multicolumn{1}{|c|}{ df1 } & \multicolumn{1}{c|}{ df2 } & \multicolumn{1}{c|}{ Sig. } \\
\hline .796 & 17 & 92 & .694 \\
\hline
\end{tabular}

Peningkatan Produktivitas Perusahaan

Dalam uji homogenitas, terdapat asumsi pengambilan keputusan, yaitu jika nilai signifikansi lebih besar dari 0,05 maka dikatakan bahwa varian dari dua kelompok populasi adalah sama. Sebaliknya, jika nilai signifikansi lebih kecil dari 0,05 maka dikatakan bahwa varian dua kelompok populasi adalah tidak sama. (Sumanto, 2014:149 - 150) Berdasarkan data tabel 5, dapat dilihat bahwa nilai signifikansi uji homogenitas ini adalah 0,694, dan nilai tersebut lebih besar dari 0,05. Maka dari itu, dapat diambil keputusan bahwa data dari variabel komunikasi downward berdasarkan variabel peningkatan produktivitas perusahaan mempunyai varian yang sama. 
Tabel 6. Coefficients ${ }^{\mathrm{a}}$

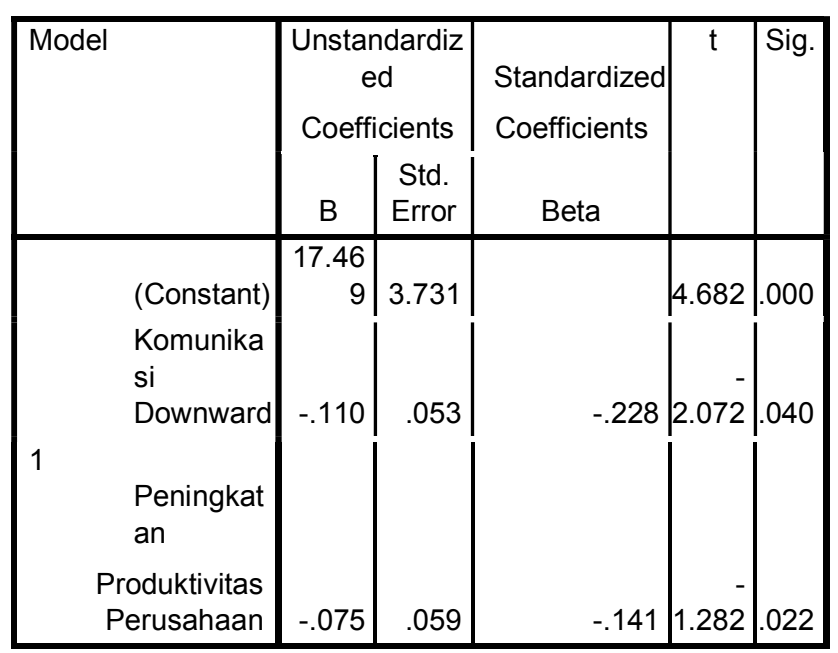

a. Dependent Variable: RES_2

$$
\text { Uji heteroskedastisitas }
$$$$
\text { memiliki asumsi dalam }
$$

keputusan dimana asumsi jika nilai

signifikansi lebih besar dari 0,05

kesimpulannya tidak terjadi

heteroskedastisitas. Sebaliknya, jika

nilai signifikansi lebih kecil dari 0,05

kesimpulannya adalah terjadi

heteroskedastisitas. Berdasarkan data tabel 6, dapat dilihat nilai signifikansi variabel komunikasi downward sebesar 0,040 dan variabel peningkatan produktivitas perusahaan sebesar 0,022. Maka, ditarik kesimpulan bahwa terjadi heteroskedastisitas variabel komunikasi downward dan variabel peningkatan produktivitas perusahaan karena lebih kecil dari 0,05.

Uji validitas untuk mengetahui kevalidan atau kesesuaian kuesioner yang peneliti gunakan untuk memperoleh data dari responden.. Uji validitas dilakukan untuk memastikan seberapa baik suatu instrumen digunakan untuk mengukur konsep yang seharusnya diukur. (Sugiyono, 2011:121)
Tabel 8. KMO and Bartlett's Test

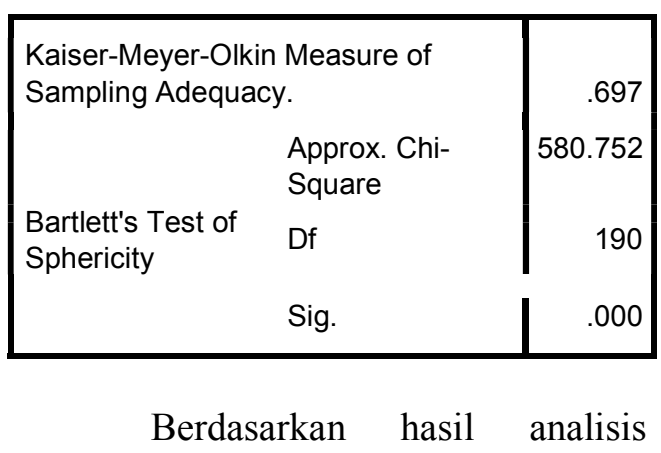

faktor pada variabel terikat, diperoleh nilai Kaiser-Meyer-Olkin-Measure of Sampling Adequancy pada tabel KMO and Bartlett's Test of Sphericity sebesar 0,697 . Hasil ini memperlihatkan bahwa instrument ini valid, karena nilai $K M O$ telah melebihi 0,5. Selain itu, nilai Bartlett's Test of Sphericity menunjukkan nilai signifikansi 0,000 sehingga dapat disimpulkan bahwa instrumen-instrumen pernyataan dalam variabel terikat ini telah memenuhi syarat valid karena nilai signifikansi lebih kecil dari 0,05.

Tahap selanjutnya dari analisis faktor adalah uji reliabilitas. Pada uji reliabilitas ini, peneliti menggunakan teknik Cronbach's Alpha. Standar nilai yang digunakan untuk menunjukkan bahwa instrumen tersebut baik adalah lebih besar dari 0,5. Semakin mendekati 1,0 maka instrumen yang dicantumkan semakin reliable. (Santoso, Singgih, 2011:47)

Analisis regresi digunakan mencari hubungan antara dua variabel atau lebih. Uji teoritis yang digunakan dalam analisis korelasi menggunakan correlations product moment, uji koefisien determinan, tabel ANOVA, dan uji signifikansi. Hubungan antara analisis korelasi dan regresi sangat erat. Analisis korelasi digunakan untuk mengetahui tingkat hubungan antara dua variabel atau lebih, sedangkan regresi digunakan mengetahui seberapa 
pengaruh variabel bebas mempengaruhi variabel terikat.

Tabel 11. Correlations

\begin{tabular}{|c|c|c|c|}
\hline & & $\begin{array}{l}\text { Komunikasi } \\
\text { Downward }\end{array}$ & \begin{tabular}{|l|} 
Peningkatan \\
Produktivitas \\
Perusahaan
\end{tabular} \\
\hline \multirow{4}{*}{$\begin{array}{l}\text { Komunikasi } \\
\text { Downward }\end{array}$} & $\begin{array}{l}\text { Pearson } \\
\text { Correlation }\end{array}$ & 1 & $.612^{* *}$ \\
\hline & $\begin{array}{l}\text { Sig. (2- } \\
\text { tailed) }\end{array}$ & & .000 \\
\hline & $\mathrm{N}$ & 120 & 120 \\
\hline & $\begin{array}{l}\text { Pearson } \\
\text { Correlation }\end{array}$ & $.612^{* *}$ & 1 \\
\hline $\begin{array}{l}\text { Peningkatan } \\
\text { Produktivitas }\end{array}$ & $\begin{array}{l}\text { Sig. (2- } \\
\text { tailed) }\end{array}$ & .000 & \\
\hline Perusahaan & $\mathrm{N}$ & 120 & 120 \\
\hline
\end{tabular}

Correlation is significant at the 0.01 level (2-tailed).

Berdasarkan tabel 11, korelasi antara variabel Komunikasi Downward dengan Peningkatan Produktivitas Perusahaan, tertera nilai korelasi antarvariabel, yakni 0,612. Mengacu pada tabel nilai koefisien korelasi, maka pada penelitian ini memiliki hubungan yang kuat. Hal tersebut memiliki arti bahwa $\rho \neq 0$ atau menolak hipotesis nol $\left(\mathrm{H}_{\mathrm{o}}\right)$ dan menerima hipotesis alternative $\left(\mathrm{H}_{\mathrm{a}}\right)$. Berdasarkan penjelasan tersebut, maka dapat ditarik pernyataan bahwa komunikasi downward berpengaruh signifikan terhadap peningkatan produktivitas perusahaan.

Tabel 12. Variables Entered/Removed ${ }^{a}$

\begin{tabular}{|l|l|l|l|}
\hline Model & $\begin{array}{l}\text { Variables } \\
\text { Entered }\end{array}$ & $\begin{array}{c}\text { Variables } \\
\text { Removed }\end{array}$ & Method \\
\hline 1 & $\begin{array}{l}\text { Komunikasi } \\
\text { Downward }\end{array}$ & & Enter \\
\hline
\end{tabular}

a. Dependent Variable: Peningkatan Produktivitas Perusahaan

b. All requested variables entered.

Tabel 12 merupakan analisis regresi, yakni dengan menggunakan backward elimination sebagai pengolahan datanya, dimana metode dengan memasukkan semua variabel kemudian dikeluarkan satu per satu dengan melakukan pengujian terhadap parameter dengan menggunakan partial F test.

Tabel 13. Model Summary

\begin{tabular}{|c|c|c|c|c|}
\hline Model & $\mathrm{R}$ & $\begin{array}{l}\mathrm{R} \\
\text { Square }\end{array}$ & $\begin{array}{l}\text { Adjusted } \\
\text { R } \\
\text { Square }\end{array}$ & $\begin{array}{l}\text { Std. } \\
\text { Error of } \\
\text { the } \\
\text { Estimate }\end{array}$ \\
\hline 1 & $.612^{a}$ & .375 & .370 & 4.820 \\
\hline \multicolumn{5}{|c|}{$\begin{array}{l}\text { a. Predictors: (Constant), Komunikasi } \\
\text { Downward } \\
\text { b. Dependent Variable: Peningkatan } \\
\text { Produktivitas Peusahaan }\end{array}$} \\
\hline
\end{tabular}

Tabel 13, nilai hubungan antara variabel independen, yaitu Komunikasi Downward dengan variabel dependen, yaitu Peningkatan Produktivitas Perusahaan. Adapun nilai korelasi antara kedua variabel tersebut adalah 0,612. Sedangkan berdasarkan tabel nilai koefisien korelasi, maka dikatakan hubungan variabel independen dan dependen dalam penelitian ini adalah kuat. Nilai kontribusi kedua variabel sebesar $37,5 \%$ yang menunjukkan pengaruh komunikasi downward terhadap peningkatan produktivitas perusahaan memiliki hubungan sisanya $62,5 \%$ disebabkan oleh faktor lain.

Tabel 14. ANOVA ${ }^{a}$

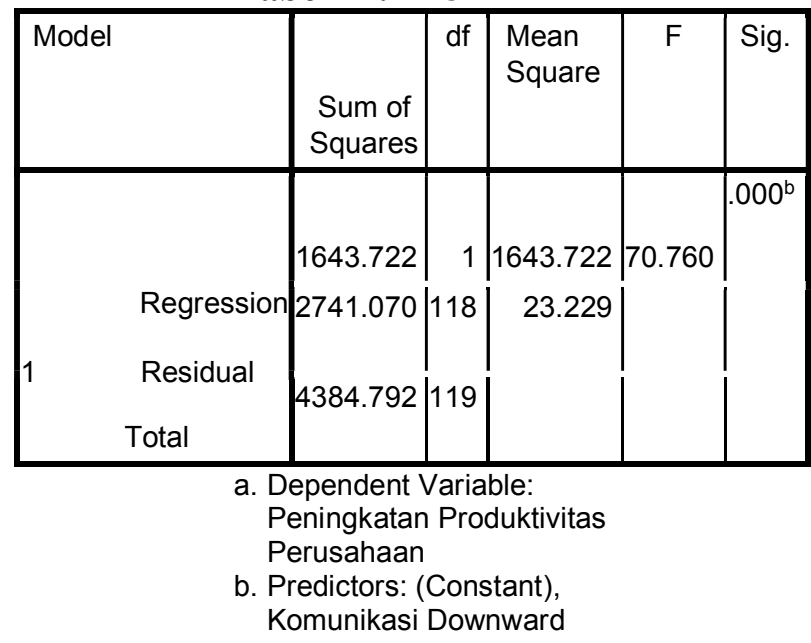

Berdasarkan tabel 14, dapat terlihat bahwa variabel independen dan dependen dalam penelitian ini memiliki 
nilai F sebesar 70,760. Selain itu, terdapat nilai signifikansi sebesar 0,000 , dimana lebih kecil dari 0,005 , maka $\mathrm{H}_{\mathrm{o}}$ yang menyatakan komunikasi downward tidak berpengaruh secara signifikan terhadap peningkatan produktivitas perusahaan ditolak. Maka $\mathrm{H}_{\mathrm{a}}$ yang menyatakan komunikasi downward berpengaruh secara signifikan terhadap peningkatan produktivitas perusahaan diterima.

Tabel 15. Coefficients ${ }^{\mathrm{a}}$

\begin{tabular}{|c|c|c|c|c|c|}
\hline Model & \begin{tabular}{r} 
Unsta \\
diz \\
Coeff \\
B \\
\multicolumn{1}{c}{}
\end{tabular} & $\begin{array}{l}\text { andar } \\
\text { ed } \\
\text { icient } \\
\text { Std. } \\
\text { Erro } \\
r\end{array}$ & \begin{tabular}{|c|}
$\begin{array}{c}\text { Standar } \\
\text { dized } \\
\text { Coefficien } \\
\text { ts } \\
\text { Beta }\end{array}$ \\
\end{tabular} & $t$ & Sig \\
\hline $\begin{array}{l}\text { Constant } \\
\text { ) } 1 \quad \text { Komunikasi } \\
\\
\quad \text { Downward }\end{array}$ & $\begin{array}{r}33.3 \\
60 \\
.556\end{array}$ & $\begin{array}{r}4.97 \\
5 \\
.066\end{array}$ & .612 & $\begin{array}{r}6.7 \\
06 \\
8.4 \\
12\end{array}$ & $\begin{array}{l}.0 \\
00 \\
.0 \\
00\end{array}$ \\
\hline
\end{tabular}

Diperoleh persamaan regresi linear sederhana yang melalui rumus: $Y$ $=\mathrm{a}+\mathrm{bX}$

Oleh karena itu, mengacu pada rumus persamaan linear sederhana: $\mathrm{Y}=$ $33,360+0,556 \mathrm{X}$. Hasil perhitungan, terdapat pernyataan bahwa nilai konstanta pada tabel unstandarized coefficients sebesar 33,360, berarti jika tidak ada variabel independen, maka variabel peningkatan produktivitas memiliki nilai 33,360, dengan nilai koefisien regresi variabel downward sebesar 0,556. Artinya, jika variabel downward mengalami kenaikan 1, maka mengalami peningkatan sebesar 0,556 .

Berdasarkan tabel 15, dapat dilihat nilai thitung sebesar 8,412 dan tabel sebesar 1,98. Karena nilai $t_{\text {hitung }}>t_{\text {tabel }}$, maka $\mathrm{H}_{\mathrm{o}}$ ditolak dan $\mathrm{H}_{\mathrm{a}}$ diterima. Artinya bahwa komunikasi downward berpengaruh signifikan terhadap peningkatan produktivitas perusahaan. Dengan thitung yang bernilai positif, maka kesimpulan bahwa komunikasi downward memiliki pengaruh positif dan signifikan terhadap peningkatan produktivitas perusahaan.

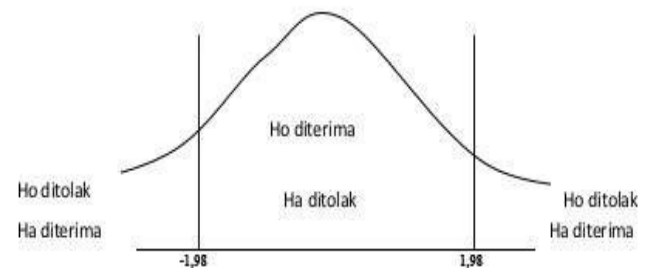

Gambar 2. Hasil penelitian

\section{Kesimpulan}

Berdasarkan hasil penelitian yang telah dilakukan, maka kesimpulan berikut: (1) Hasil penelitian menunjukkan komunikasi downward berpengaruh signifikan terhadap intensi, kekhususan, deksriptif, kemanfaatan, tepat waktu, kesiapan, kejelasan, dan validitas PT Sasa Inti. (2) Terdapat peningkatan produktivitas perusahaan berpengaruh secara signifikan terhadap produktivitas fisik dan produktivitas nilai PT Sasa Inti. (3) Komunikasi downward berpengaruh signifikan terhadap peningkatan produktivitas perusahaan pada PT Sasa Inti.

\section{Daftar Pustaka}

(1995), R. R. (2018). Production and Operation Management, New Jersey, Prentice Hall, Inc. Inter Komunika, Stikom InterStudi.

(1995), S. B. (2018). Communication in Business, New Jarsey: Prentice Hall, Inc Engelwood Cliffs. Inter Komunia, Stikom InterStudi.

(1995), S. R. (2018). Communication in Business, New Jersey : Prentice Hall, Inc. Engelwood Cliffs. Inter Komunika, Stikom InterStudi. 
(1997), G. (2018). Organizational Communication, Brown Publisher. Inter Komunika, Stikom InterStudi.

(1997), J. A. (2018). Teori - Teori Ilmu Komunikasi, Professional Book, Jakarta. Inter Komunika, Stikom InterStudi.

(1998), W. P. (2018). Organisasi Strategi Meningkatkan Perusahaan, Rosdakarya, Bandung. Inter Komunika, Stikom InterStudi.

(2000), S. (2018). Latihan SPSS Statistik Parametrik, Elex Media Komputindo Gramedia, Jakarta. Inter Komunika, Stikom InterStudi.

(2001), F. J. (2018). The New Handbook of Organization Communication : Advance in Theory, Research and Method, London . Inter Komunika, Stikom InterStudi.

(2003), D. P. (2018). Komunikasi Bisnis, Erlangga, Jakarta. Inter Komunika, Stikom InterStudi.

(2003), M. \&. (2018). Human Resource Management, Prentice Hall, Singapore. Inter Komunika, Stikom InterStudi.

(2004), A. M. (2018). Komunikasi Organisasi, Bumi Aksara Jakarta. Inter Komunika, Stikom InterStudi.

(2004), A. M. (2018). Komunikasi Organisasi, Bumi Aksara, . Inter Komunika, Stikom InterStudi.

(2004), R. (2018). Metode dan Teknik Menyusun Tesis, Alfabeta, Bandung. Inter Komunika, Stikom InterStudi.

(2005), F. d. (2018). Komunikasi Organisasi, Strategi Meningkatkan Kinerja, Remaja Rosdakarya, Bandung. Inter Komunika, Stikom InterStudi.

(2005), M. T. (2018). Kepemimpinan Dalam Manajemen, Rajawali Pers, Jakata. Inter Komunika, Stikom InterStudi.
(2005), S. P. (2018). Manajemen, Jakarta Indeks. Inter Komunika, Stikom InterStudi.

(2005), W. (2018). Pengantar Ilmu Komunikasi, Gramedia Wisarana Indonesia. Inter Komunika, Stikom InterStudi.

(2006), B. A. (2018). Manajemen Pemasaran dan Pemasaran Jasa, Alfabeta, Bandung. Inter Komunika, Stikom InterStudi.

(2006), D. M. (2018). Komunikasi Organisasi, Strategi Meningkatkan Kinerja Perusahaan, Remaja Rosdakarya, Bandung. Inter Komunika, Stikom InterStudi.

(2006), S. P. (2018). Perilaku Organisasi, Indeks Kelompok Gramedia, Jakarta. inter Komunika, Stikom InterStudi.

(2007), H. (2018). Metode Penelitian dan Teori Komunikasi, UMM, Malang. Inter Komunika, Stikom InterStudi.

(2007), R. d. (2018). Pengantar Statistik untuk Penelitian, Alfabeta, Bandung. Inter Komunika, Stikom InterStudi.

(2008), S. (2018). Metode Penelitian Kuantitatif, Kualitatif dan R \& D, Alfabeta, Bandung. Inter Komunika, Stikom InterStudi.

(2008), S. (2018). Metode Penelitian Kuantitatif, Kulaitatif dan R\&D, Alfabeta Bandung. Inter Komunika, Stikom InterStudi.

(2008), S. P. (2018). Perilaku Organisasi, Salemba Empat, Jakarta. Inter Komunika, Stikom InterStudi.

(2009), S. (2018). Metode Penelitian Kuantitatif, Kualitatif dan R\&D, Alfabeta, Bandung. Inter Komunika, Stikom InterStudi.

(2009), S. (2018). Statistika untuk Penelitain, Alfabeta, Bandung. Inter Kounika, Stikom InterStudi.

(2009), Y. I. (2018). Media Relations Konsep, Pendekatan dan Praktik, Simbiosa Rekatama Media, 
Bandung. Inter Komunika, Stikom InterStudi.

(2010), S. (2018). Pengantar Manajemen, Bumi Aksara, Jakarta. Inter Komunika, Stikom InterStudi.

(2011), S. (2018). Metode Penelitian Kuantitatif, Kualitatif dan R \& D, Alfabeta, Bandung. Inter Komunika, Stikom InterStudi.

(2011), W. M. (2018). Ketrampilan dan Strategi Komunikasi Bisnis, CAPS, Yogyakarta. Inter Komunika, Stikom InterStudi.

(2014), S. (2018). Statistika Terapan, Caps Jakarta. Inter Komunika, Stikom InterStudi.

(2014), S. (2018). Statistika Terapan, CAPS Jakarta. Inter Komunika, Stikom InterStudi.

(2014), S. (2018). Statistika Terapan, CAPS Jakarta. Inter Komunika, Stikom InterStudi.

(2015), h. p. (2018). Sasa Inti Company Profile. Inter Komunika, Stikom InterStudi.

Arikunto, S. (. (2018). Prosedur Penelitian : Pendekatan Praktek, Rineka Cipta, Jakarta. Inter Komunika, Stikom InterStudi.

Arikunto, S. (. (2018). Prosedur Suatu Penelitian: Pendekatan Praktek, Rineka Cipta, Jakarta. Inter Komunika, Stikom InterStudi.

Arni, M. (. (2018). Komunikasi Organisasi, Bumi Aksara, Jakarta. Inter Komunika, Stikom InterStudi.

Baty, W. C. (2018). Business Communication: Principles and Methods, Kentucky: Po.Co. Inter Komunika, Stikom InterStudi.

Bhuono, N. (. (2018). Strategi Jitu Memilih Statistik Penelitian Dengan SPSS, Andi Offset, Yogyakarta. Inter Komunika, Stikom InterStudi.

Bovee, C. L. (2018). Business Communication Today, Prenhallindo, Jakarta. Inter Komunika, Stikom InterStudi.
Bungin, B. H. (2018). Metode Penelitian Kualitatif, Prenada Media, Jakarta. Inter Komunika, Stikom InterStudi.

Bungin, B. H. (2018). Metode Penelitian Kuantitatif, Prenada Media, Jakarta. Inter Komunika, Stikom InterStudi.

Courtland L.Bovee dan Thill, J. V. (2018). Business Communication Today, Prenhallindo, Jakarta. Inter Komunika, Stikom InterStudi.

Effendy, U. O. (2018). Hubungan Masyarakat Suatu Studi Komunikologis, Remaja Rosdakarya, Bandung. Inter Komunika, Stikom InterStudi.

Ghozali, I. (. (2018). Aplikasi Analisis Multivariate dengan Program SPSS, BP. Undip Semarang. Inter Komunika, Stikom InterStudi.

Guilford J.P., (. (2018). Fundamental Statisic in Phychology and Education, McGraw-Hill BC.Inc NY. Inter Komunika, Stikom InterStudi.

Herjanto, E. (. (2018). Manajemen Operasi, Grasindo Persada. inter Komunika, Stikom InterStudi.

Ivancevich, J. M. (2018). Perilaku dan Manajemen Organisasi, Erlangga, Jakarta. Inter Komunika, Stikom InterStudi.

Kriyantono, R. (. (2018). Teknik Praktis: Riset Komunikasi, Kencana Prenada Media Group, Jakarta. Inter Komunika, Stikom InterStudi.

Littlejohn, S. W. (2018). Theories of Human Communication, Salemba, Jakarta. Inter Komunika, Stikom InterStudi.

Luthans, F. (. (2018). Perilaku Organisasi, Andi Offset, Yogyakarta. Inter Komunika, Stikom InterStudi.

Martono, N. (. (2018). Metode Penelitian Kuantitatif, Raja 
Grafindo Persada, Jakarta. Inter Komunika, Stikom InterStudi.

Moloeng, L. J. (2018). Metodologi Penelitian Kualitatif, Remaja Rosda Karya. Inter Komunika, Stikom InterStudi.

Nawawi, H. (. (2018). Metode Penelitian Bidang Sosial, Gajah Mada University Press, Yogyakarta. Inter Komunika, Stikom InterStudi.

Neuman, L. M. (2018). Social Research Methods (Qualitative \& Quantitative Approaches, USA. Inter Komunika, Stikom InterStudi.

Ricky W.Griffin dan Ebert, R. J. (2018). Pengantar Bisnis, Erlangga, Jakarta. Inter Komunika, Stikom InterStudi.

Riyanto(2017). (2018). Efektivitas Media Internet terhadap Kepuasan Khalayak Media, Inter komunika. Inter Komunika, Stikom InterStudi.

Ruslan, R. (. (2018). Manajemen Public Relation dan Media Komunikasi, Raja Grafindo Persada, Jakarta. Inter Komunika, Stikom InterStudi.

Ruslan, R. (. (2018). Manajemen Public Relations dan Media Komunikasi, Raja Grafindo Persada, Jakarta. Inter Komunika, Stikom InterStudi.

Santoso, G. (. (2018). Metodologi Penelitian, Prestasi Pustaka Publisher, Jakarta. Inter Komunika, Stikom InterStudi.

Santoso, S. (. (2018). Statistik Parametik, Elex Media Komputindo, Jakarta. Inter Komunika, Stikom InterStudi.

Siagian, S. P. (2018). Kiat Meningkatkan Produktivitas Kerja, Rineka Cipta, Jakarta. inter Komunika, Stikom InterStudi.

Simanjuntak, P. J. (2018). Manajemen dan Evaluasi Kinerja, FEUI. Inter Komunika, Stikom InterStudi.

Sinungan, M. (2018). Produktivitas, apa dan Bagaimana, Bumi Aksara, Jakarta. Inter Komunika, Stikom InterStudi.
Soehartono, I. (. (2018). Metode Penelitian Sosial, Remaja Rosdakarya. Inter Komunika, Stikom InterStudi.

Sugiyono(2009). (2018). Statistik untuk Penelitian, Alfabeta, Bandung. Inter Komunika, Stikom InterStudi.

Sutrisno, E. (. (2018). Manajeman Sumber Daya Manusia, Prenada Kencana. Inter Komunika, Stikom InterStudi.

Sutrisno, E. (. (2018). Manajemen Sumber Daya Manusia, Prenada Kencana, Jakarta. Inter Komunia, Stikom InterStudi.

Tjiptono, F. (. (2018). Strategi Bisnis Pemasaran, Andi Offset, Yogyakarta. Inter Komunika, Stikom InterStudi.

Yuniarsih, T. d. (2018). Manajemen Sumber Daya Manusia, Alfabetha, Bandung. Inter Komunika, Stikom InterStudi. 